Research article

\title{
The efficacy of chemical agents in cleaning and disinfection programs
}

\author{
Thereza Christina Vessoni Penna*, Priscila Gava Mazzola and \\ Alzira Maria Silva Martins
}

Address: Department of Biochemical and Pharmaceutical Technology, School of Pharmaceutical Sciences, University of São Paulo, São Paulo, Brazil

E-mail: Thereza Christina Vessoni Penna* - tcvpenna@usp.br; Priscila Gava Mazzola - priscila_mazzola@hotmail.com; Alzira Maria Silva Martins-martina3@baxter.com

*Corresponding author

Published: 24 September 2001

Received: 3 August 200I

BMC Infectious Diseases 200I, I:16

Accepted: 24 September 2001

This article is available from: http://www.biomedcentral.com/I47/-2334/I//6

(C) 200I Penna et al; licensee BioMed Central Ltd. Verbatim copying and redistribution of this article are permitted in any medium for any non-commercial purpose, provided this notice is preserved along with the article's original URL. For commercial use, contact info@biomedcentral.com

\begin{abstract}
Background: Due to the growing number of outbreaks of infection in hospital nurseries, it becomes essential to set up a sanitation program that indicates that the appropriate chemical agent was chosen for application in the most effective way.

Method: For the purpose of evaluating the efficacy of a chemical agent, the minimum inhibitory concentration (MIC) was reached by the classic method of successive broth dilutions. The reference bacteria utilized were Bacillus subtilis var. globigii ATCC 9372, Bacillus stearothermophilus ATCC 7953, Escherichia coli ATCC 25922, Staphylococcus aureus ATCC 25923. The strains of Enterobacter cloacae IAL 1976 (Adolfo Lutz Institute), Serratia marcescens IAL I 478 and Acinetobactev calcoaceticus IAL 124 (ATCC 19606), were isolated from material collected from babies involved in outbreaks of infection in hospital nurseries.

Results: The MIC intervals, which reduced bacteria populations over $08 \log _{10}$, were: 59 to 156 $\mathrm{mg} / \mathrm{L}$ of quaternarium ammonium compounds (QACs); 63 to $10000 \mathrm{mg} / \mathrm{L}$ of chlorhexidine digluconate; 1375 to $3250 \mathrm{mg} / \mathrm{L}$ of glutaraldehyde; 39 to $246 \mathrm{mg} / \mathrm{L}$ of formaldehyde; 43750 to 87500 $\mathrm{mg} / \mathrm{L}$ of isopropanol or ethanol; 1250 to $6250 \mathrm{mg} / \mathrm{L}$ of iodine in polyvinyl-pyrolidone complexes, 150 to $4491 \mathrm{mg} / \mathrm{L}$ of chlorine-releasing-agents (CRAs); 469 to $2500 \mathrm{mg} / \mathrm{L}$ of hydrogen peroxide; and, 2310 to $18500 \mathrm{mg} / \mathrm{L}$ of peracetic acid.
\end{abstract}

Conclusions: Chlorhexidine showed non inhibitory activity over germinating spores. A. calcoaceticus, was observed to show resistance to the majority of the agents tested, followed by $E$. cloacae and S. marcescens.

\section{Background}

The Ministry of Health in Brazil is concerned about hospital infections, which have involved an average of 13 of every 100 patients admitted into hospitals of the Brazil- ian National Health System (SUS), the maximum tolerable being $5.7 \%$ according to the World Health Organization (WHO) [1]. Had good hygienic practices and the rational use of antibiotics been employed, it is es- 
timated that $1 / 3$ of the cases could have been avoided. Furthermore, the government lacks sufficient information on the incidence of hospital infections in different regions of the country, so in 1998, the Ministry of Health made it mandatory to notify such cases. Unfortunately, less than $20 \%$ of Brazilian hospitals have adequate hospital infection control structures and preventive programs [2].

In 1997, the Pan American Health Organization (PAHO) [3] stated that 17 million people worldwide were fatal victims of hospital infections in 1995, as a consequence of the abandonment of sanitary vigilance programs and a reduction of investments in basic sanitation projects. PAHO [4] alerted that more than 250,000 children, under 5 years of age die annually in the Americas, from illnesses that can be easily prevented or treated.

In October 1996, according to feces and urine samples collected from new born babies, the genera Acinetobacter calcoaceticus, which can be fatal in $48 \mathrm{~h}$ to infected infants, was confirmed as the responsible agent for the death of infants in maternity hospitals in Boa Vista (Rondonia). Two babies hospitalized in November 1997, in a São Paulo Neonatal Intensive Care Unit, were infected by Serratia marcescens, which was the cause of 15 deaths of new born babies since August 1997. A further eleven babies, although infected during this period, reacted following antibiotic treatment. In November 1997 , Enterobacter cloacae was confirmed to have infected 10 babies in a São Paulo Maternity. This Hospital has an average of 400 births monthly, ten percent of which could be infected. The bacterium was also involved in six deaths of infected babies in less than a week in October 1999, in a Rio de Janeiro Maternity. In a short period of time (October 1999 to January 2000), at least 24 deaths of babies from hospital infections were notified in Brazil. The origins of the infection by $A$. calcoaceticus, $E$. cloacae and $S$. marcescens remain uncertain, regardless of the fact that cross-contamination maintains the spread of the microorganism [3,5]. These data are frightening since they reflect a disheartening tendency for old microorganisms to reappear.

PAHO, WHO, national and international agencies and non-governmental organizations (NGOs) hope to prevent 100,000 deaths in children under 5 years of age in the Americas by 2002 by improving the training of health professionals, the quality of the health system required for effective administration of childhood illnesses and family and community practices [4].

Efforts to diminish the risk of transmission of infections include programs in which these infections have a crucial role. The surfaces of hospital medical devices, the skin of the personnel, equipment, furniture and areas should be disinfected by an appropriate disinfecting agent and one which is easily acquired and handled, is harmless and easily disposed of should be chosen. But it is difficult to select an appropriate disinfecting agent because there is a large variety on the market, therefore it is imperative to identify the principal microorganisms encountered in health care centers before making the selection.

For the purpose of evaluating the range of activity of commercial sanitation products for hospital use against the bacteria involved in the deaths of new born babies in Brazil, the minimum inhibitory concentration (MIC) was determined by the classical method of successive broth dilutions.

\section{Methods \\ Cultures of microorganisms}

The bacterial strains, obtained from the collection of lyophilized cultures by the Adolfo Lutz Institute (IAL, SP, Brazil), were Enterobacter cloacae IAL 1976; Serratia marcescens IAL 1478; Acinetobacter calcoaceticus ATCC 19606, IAL 124. The reference bacteria used were Escherichia coli ATCC 25922, Staphylococcus aureus ATCC 25923, Bacillus subtilis var. globigii ATCC 9372, and Bacillus stearothermophilus ATCC 7953. Working cultures were kept on Tryptic soy agar (TSA, Difco, Detroit, Michigan, USA) at $4^{\circ} \mathrm{C}$ with weekly transfers. The $24 \mathrm{~h}$ cultures, developed on TSA, at $22^{\circ} \mathrm{C}$ for $S$. marcescens, and at $35^{-}-37^{\circ} \mathrm{C}$ for E. cloacae, A. calcoaceticus, $E$. coli; $S$. aureus, were harvested in Tryptic soy broth (TSB, Difco), centrifuged (1000 g/ $15 \mathrm{~min} / 4^{\circ} \mathrm{C}$ ) and suspended in saline. Bacteria viability was estimated through pour plate on TSA, confirming populations over $107 \mathrm{CFU} / \mathrm{mL}$. Spore cultures, developed for 6-days on a sporulation medium (g.L ${ }^{-1}$ : D-glucose (Sigma, St. Louis, Missouri, USA), 2.5; L-glutamic acid (Sigma), 0.4; yeast extract (Difco), 4.O; peptone (Difco), 5.0; sodium chloride, 0.01; manganese sulfate, O.O1; bacteriologic (Difco) agar, 20.0), at $37^{\circ} \mathrm{C}$ for B. subtilis, and at $62^{\circ} \mathrm{C}$ for B. stearothermophilus, were harvested, centrifuged (1935 $\mathrm{g}$ for 30 min, four times), and kept suspended in cooling $0.02 \mathrm{M}$ calcium acetate solution $(\mathrm{pH}=9.7)$ at $4^{\circ} \mathrm{C}[6]$. The viability of heat-shocked $\left(80^{\circ} \mathrm{C} / 10 \mathrm{~min}\right.$ for $B$. subtilis and $100^{\circ} \mathrm{C} / 20 \mathrm{~min}$ for $B$. stearothermophilus) spores was obtained through pour plate on TSA, confirming populations over $10^{6}$ spores $/ \mathrm{mL}$.

\section{Chemical agents}

Chlorhexidine digluconate (biguanide, 1.6-dichorophenyldiguanido hexane; 40\% w/v; Zeneca Farmacêutica, $\mathrm{SP}, \mathrm{Br}$ ); hydrogen peroxide (40\% w/v, Laborasa Farmacêutica, SP, Br), kept at $4^{\circ} \mathrm{C}$; isopropyl alcohol $(70 \% \mathrm{v} / \mathrm{v}$, Johnson and Johnson -J\&J -, SP, Br) and sodium dichloro-isocyanurate ( $\mathrm{NaDCC}$, sodium salt $50 \% \mathrm{w} / \mathrm{w}$ in tab- 
lets, J\&J) were tested. The following solutions were from Aster Produtos Medicos (SP, Br): ethanol (70\%, v/v); ethanol $(70 \% \mathrm{v} / \mathrm{v})$ plus glycerin $(2 \% \mathrm{w} / \mathrm{v})$; glutaraldehyde (1.5 pentanedial; $2.0 \% \mathrm{w} / \mathrm{v}$ alkalinized with sodium bicarbonate, $\mathrm{pH}=8.3$ ), formaldehyde (monoaldehyde; $37 \% \mathrm{w} / \mathrm{v})$; sodium hypochlorite $(10 \% \mathrm{w} / \mathrm{v})$; peracetic acid $(37 \% \mathrm{w} / \mathrm{v})$ kept at $4{ }^{\circ} \mathrm{C}$; quaternarium ammonium compounds - QACs $(10 \% \mathrm{w} / \mathrm{v}$, benzalkonium chloride, monoquaternary mixture of alkyldimethylbenzylammonium chlorides); aqueous polyvinylpyrolidone-iodine $\left(10 \% \mathrm{w} / \mathrm{v}, \mathrm{PVP}-\mathrm{I}_{2}\right.$, topic and soap) solution, with and without sodium lauryl ether sulfate $(25 \% \mathrm{w} / \mathrm{v})$; alcoholic polyvinylpyrolidone-iodine (10\% w/v, $\mathrm{PVP}-\mathrm{I}_{2}$, alcoholic) in ethanol $70 \%(\mathrm{v} / \mathrm{v})$. Ethanol at $70 \% \mathrm{v} / \mathrm{v}$, added with iodine $1 \% \mathrm{w} / \mathrm{v}$ and $10 \% \mathrm{w} / \mathrm{v}$; and sodium hypochlorite at $\mathrm{pH}$ 7.0 in Sorensen phosphate-buffered solution were prepared at the laboratory. The concentration of total available chlorine, iodine and hydrogen peroxide was determined by the iodometric method [7]. The diluted so- lutions, prepared with chlorine demand-free glassware, were filtered through a $0.22-\mu \mathrm{m}$-pore-size membrane (Millipore, Bedford, MA, USA) for daily use. The chemical agents have their usage for hospital disinfection purposes approved by the Brazilian Ministry of Health [8].

\section{Minimal inhibitory concentration}

The minimal inhibitory concentration (MIC) was determined by using the two-fold broth dilution method [9]. Starting from a chemical agent solution, serial dilutions were prepared in TSB inoculated with the test bacterial populations $\geq 10^{6} \mathrm{CFU} / \mathrm{mL}$. The MIC was identified as the lowest concentration of the chemical agent, which resulted in confirmed inhibition of the growth of the tested microorganism, after $24 \mathrm{~h}$ of optimal incubation conditions. The chemical agent solutions, started concentrations and $\mathrm{pH}$ values are presented in Table 1 . The MICs were expressed in percentage and in $\mathrm{mg} / \mathrm{L}$ and are shown in Table 2.

Table I: Started solutions of chemical agents, their concentrations and pH values, which were used for the MIC tests.

\begin{tabular}{|c|c|c|}
\hline Chemical Agent & $\begin{array}{c}\text { Solution } \\
\text { Concentrations (\%) }\end{array}$ & $\begin{array}{l}\text { Solution } \\
\mathrm{pH} \text { values }\end{array}$ \\
\hline QACs - Quaternarium Ammonium Compounds & 0.5 & $6.3-6.9$ \\
\hline Chlorhexidine digluconate & $4.0,0.1,1.0$ & $6.18-6.95$ \\
\hline Glutaraldehyde & $2.0,1.5$ & 7.14 \\
\hline Formaldehyde & $0.5,2.3$ & 7.79 \\
\hline \multirow[t]{2}{*}{ Alcohol: Ethanol $(\mathrm{EtOH})$ or Isopropanol } & 70.0 & $5.50(\mathrm{EtOH})$ \\
\hline & 70.0 & 6.59 (Isopropanol) \\
\hline Ethanol $(\mathrm{EtOH})$ plus glycerin & $70.0(\mathrm{EtOH})+2.0($ glycerin $)$ & 5.94 \\
\hline \multirow[t]{2}{*}{ Ethanol $(\mathrm{EtOH})$ plus iodine } & $70.0(\mathrm{EtOH})+1.0\left(\mathrm{I}_{2}\right)$ & 5.50 \\
\hline & $70.0(\mathrm{EtOH})+10.0\left(\mathrm{I}_{2}\right)$ & 5.50 \\
\hline $\mathrm{Pvp}_{2} \mathrm{I}_{2}$ - topic: Aqueous polyvinylpyrolidone-iodine & $10.0\left(I_{2}\right)$ & $5.32-5.95$ \\
\hline $\mathrm{Pvp}-\mathrm{I}_{2}$ - soap - Aqueous Pvp-I $\mathrm{I}_{2}$ into lauryl ether sulfate $(25 \% \mathrm{w} / \mathrm{v})$ & $10.0\left(I_{2}\right)$ & 5.72 \\
\hline$P v p-I_{2}-$ Alcoholic Pvp-I $I_{2}$ into ethanol $(70 \% v / v)$ & $10.0\left(I_{2}\right)$ & $2.04-2.90$ \\
\hline CRAs - Chlorine releasing agents - Sodium hypochlorite $(\mathrm{NaOCl})$ into & 1.0 total free chlorine & $>9.0$ \\
\hline phosphate buffer at $\mathrm{pH}=7.0$ & 0.1 total free chlorine & $7.0-7.6$ \\
\hline $\mathrm{NaDCC}$ - Sodium dichloro-isocyanurate & 1.0 total free chlorine & 6.70 \\
\hline $\mathrm{H}_{2} \mathrm{O}_{2}-$ Hydrogen Peroxide & 4.0 & 3.3 \\
\hline Peracetic Acid (PAA) at 3.7\%. $\mathrm{pH}=3.03$. & 3.7 & 3.03 \\
\hline
\end{tabular}

\section{Results and Discussion}

The chemical agents studied in commercial sanitation products are extensively used in health care settings for topical and hard-surface applications.

\section{Quaternarium ammonium compounds - QACs}

QACs are not sporocidal, their activity exhibiting inhibition of the outgrowth [10] of germinating spores. The MICs of $0.0117-0.0156 \%(117-156 \mathrm{mg} / \mathrm{L})$ for $B$. subtilis and $B$. stearothermophilus were twice those exhibited by vegetative cells of $E$. cloacae, E. coli, $S$. aureus and $S$. marcescens, with a MIC ranging from 0.0059-0.0078\% $(59-78 \mathrm{mg} / \mathrm{L})$, four times greater than the MIC $(9.77$ $\mathrm{mg} / \mathrm{L}$ ) observed for A. calcoaceticus.

\section{Comments}

In health care settings, the QACs, considered low-level disinfectants, are used in a minimum concentration of $0.2 \%(2000 \mathrm{mg} / \mathrm{L})$, without formaldehyde in their formulation [8]. The QACS are mostly applied as antiseptic and on hard surfaces due to being non aggressive and releasing residual antimicrobial activity, respectively, re- 
Table 2: The minimum inhibitory concentrations (MIC) for the chemical agent solutions to reduce bacteria populations over 6-log 10 .

\begin{tabular}{|c|c|c|c|c|c|c|c|c|c|c|c|c|c|c|}
\hline \multirow{2}{*}{$\begin{array}{c}\text { Bacteria } \\
\text { MIC }\end{array}$} & \multicolumn{2}{|c|}{$\begin{array}{c}\text { Bacillus } \\
\text { stearothermophilus }\end{array}$} & \multicolumn{2}{|c|}{ Bacillus subtilis } & \multicolumn{2}{|c|}{$\begin{array}{l}\text { Acinetobacter } \\
\text { calcoaceticus }\end{array}$} & \multicolumn{2}{|c|}{$\begin{array}{l}\text { Enterobacter } \\
\text { cloacae }\end{array}$} & \multicolumn{2}{|c|}{ Escherichia coli } & \multicolumn{2}{|c|}{$\begin{array}{c}\text { Serratia } \\
\text { marcescens }\end{array}$} & \multicolumn{2}{|c|}{$\begin{array}{c}\text { Staphylococcus } \\
\text { aureus }\end{array}$} \\
\hline & $\mathrm{mg} / \mathrm{L}$ & $\%$ & $\mathrm{mg} / \mathrm{L}$ & $\%$ & $\mathrm{mg} / \mathrm{L}$ & $\%$ & $\mathrm{mg} / \mathrm{L}$ & $\%$ & $\mathrm{mg} / \mathrm{L}$ & $\%$ & $\mathrm{mg} / \mathrm{L}$ & $\%$ & $\mathrm{mg} / \mathrm{L}$ & $\%$ \\
\hline \multicolumn{15}{|l|}{ Agent } \\
\hline QACs & 156 & 0.0156 & 117 & $\begin{array}{c}0.011 \\
7\end{array}$ & 9.77 & $\begin{array}{c}0.001 \\
0\end{array}$ & 78 & 0.0078 & 59 & $\begin{array}{c}0.005 \\
9\end{array}$ & 59 & 0.0059 & 59 & 0.0059 \\
\hline Chlorhexidine & $*$ & $*$ & 10000 & 1.0 & 63 & $\begin{array}{c}0.006 \\
3\end{array}$ & 71 & 0.007 I & 71 & $\begin{array}{c}0.007 \\
1\end{array}$ & 141 & 0.0141 & 71 & 0.0071 \\
\hline Glutaraldehyde & 1875 & 0.1875 & 3250 & 0.325 & 3250 & 0.325 & 3250 & 0.325 & 3250 & 0.325 & 1375 & 0.1375 & 1875 & 0.1875 \\
\hline Formaldehyde & 246 & 0.0246 & 235 & $\begin{array}{c}0.023 \\
5\end{array}$ & 39 & $\begin{array}{c}0.003 \\
9\end{array}$ & 117 & 0.0117 & 156 & $\begin{array}{c}0.015 \\
6\end{array}$ & 58.5 & 0.0059 & 156 & 0.0156 \\
\hline Alcohol & 87500 & 8.75 & 87500 & 8.75 & 43750 & 4.375 & 87500 & 8.75 & $\begin{array}{c}6565 \\
0\end{array}$ & 6.565 & $\begin{array}{c}4375 \\
0\end{array}$ & 4.375 & 87500 & 8.75 \\
\hline $\begin{array}{l}\mathrm{EtOH}(+ \text { glyc- } \\
\text { erin) }\end{array}$ & $*$ & $*$ & $*$ & $*$ & 87500 & 8.75 & 87500 & 8.75 & $\begin{array}{c}8750 \\
0\end{array}$ & 8.75 & $\begin{array}{c}8750 \\
0\end{array}$ & 8.75 & 87500 & 8.75 \\
\hline $\mathrm{EtOH}\left(+\mathrm{I}_{2} \mathrm{I} \%\right)$ & 87500 & 8.75 & 87500 & 8.75 & 43750 & 4.375 & 87500 & 8.75 & $\begin{array}{c}4375 \\
0\end{array}$ & 4.375 & $\begin{array}{c}4375 \\
0\end{array}$ & 4.375 & 43750 & 4.375 \\
\hline $\mathrm{I}_{2} 1 \%$ in $\mathrm{EtOH}$ & 1250 & 0.125 & 1250 & 0.125 & 1250 & 0.125 & 1250 & 0.125 & 625 & $\begin{array}{c}0.062 \\
5\end{array}$ & 625 & 0.0625 & 625 & 0.0625 \\
\hline $\mathrm{EtOH}\left(+\mathrm{I}_{2} \quad 10 \%\right)$ & - & - & 43750 & 4.375 & - & - & 43750 & 4.375 & - & - & - & - & 21870 & 2.187 \\
\hline $\mathrm{I}_{2} 10 \%$ in $\mathrm{EtOH}$ & - & - & 6250 & 0.625 & - & - & 6250 & 0.625 & - & - & - & - & 3125 & 0.313 \\
\hline Pvp-I-12-topic & 12500 & 1.25 & 50000 & 5.0 & 12500 & 1.25 & 6250 & 0.625 & $\begin{array}{c}1250 \\
0\end{array}$ & 1.25 & 6250 & 0.625 & 6250 & 0.625 \\
\hline $\mathrm{Pvp}-\mathrm{I}_{2}-$ soap & 6250 & 0.625 & 50000 & 5.0 & 6250 & 0.625 & 6250 & 0.625 & 6250 & 0.625 & 6250 & 0.625 & 6250 & 0.625 \\
\hline $\mathrm{Pvp}-\mathrm{I}_{2}-$ alcoholic & 12500 & 1.25 & 25000 & 2.5 & 12500 & 1.25 & 3125 & 0.3125 & 1560 & 0.156 & 3125 & 0.3125 & 3125 & 0.3125 \\
\hline CRAs $1 \% \mathrm{pH}>9$ & 4491 & 0.4491 & 4491 & $\begin{array}{c}0.449 \\
1\end{array}$ & 867 & $\begin{array}{c}0.086 \\
7\end{array}$ & 420 & 0.0420 & 1129 & $\begin{array}{c}0.112 \\
9\end{array}$ & 474 & 0.0474 & 945 & 0.0945 \\
\hline CRAs $0.1 \% \mathrm{pH} 7$ & 621 & 0.0621 & 621 & $\begin{array}{c}0.062 \\
1\end{array}$ & 150 & 0.015 & 150 & 0.015 & 150 & 0.015 & 150 & 0.015 & 150 & 0.015 \\
\hline $\mathrm{NaDCC}$ & 5990 & 0.599 & 5990 & 0.599 & 1123 & $\begin{array}{c}0.112 \\
3\end{array}$ & 374 & 0.0374 & 1123 & $\begin{array}{c}0.112 \\
3\end{array}$ & 187 & 0.0187 & 749 & 0.0749 \\
\hline $\mathrm{H}_{2} \mathrm{O}_{2}$ & 1875 & 0.1875 & 1875 & $\begin{array}{l}0.187 \\
5\end{array}$ & 469 & $\begin{array}{c}0.046 \\
9\end{array}$ & 1250 & 0.125 & 2505 & 0.250 & 625 & 0.0625 & 938 & 0.0938 \\
\hline Peracetic acid & 4620 & 0.4620 & 18500 & 1.85 & 9250 & 0.925 & 9250 & 0.925 & 2310 & 0.231 & 9250 & 0.925 & 4620 & 0.462 \\
\hline
\end{tabular}

Legend: QACs - Quaternarium Ammonium Compounds; $\mathrm{H}_{2} \mathrm{O}_{2}-$ Hydrogen peroxide Alcohol - Ethanol (EtOH) or Isopropanol; EtOH $+\mathrm{I}_{2}$ (iodine); Pvp-I 2 - polyvinylpyrolidone-iodine CRAs - Chlorine releasing agents (CRAs) - Sodium hypochlorite $(\mathrm{NaOCl}) ; \mathrm{NaDCC}-\mathrm{Sodium}$ dichloro-isocyanurate ${ }^{*}$ no efficacy)

placing phenol compounds. In hospital nurseries, the QCAs should be used in the disinfection of beds, matrix and general hard surfaces in order to minimize crosscontamination and the risk of exceeding super population, which occurs frequently in the SUS Hospitals.

\section{Chlorhexidine digluconate}

In Brazilian Hospitals, the concentration of $4.0 \%$ chlorhexidine solution is used for hand washing by the medical staff. In our study, chlorhexidine showed no efficacy over B. stearothermophilus, and a MIC of $1.0 \%$ for $B$. subtilis. The MIC interval of $0.0063-0.0071 \%(63-71$ $\mathrm{mg} / \mathrm{L}$ ) was observed for E. cloacae, E. coli and S. aureus, and for S. marcescens, the MIC was $0.0125-0.0156 \%$ (125-156 mg/L), therefore double that of the former.

\section{Comments}

Solution of chlorhexidine at $4 \%$, containing $4 \%$ of alcohol (to prevent cross contamination with proteus and pseudomonas) [8], is widely applied for degermination of the hands of personnel and topic for pre-surgical areas. An alcoholic solution of chlorhexidine at $0.5 \%$ is indicated as a topical antiseptic, to replace PVP- $\mathrm{I}_{2}$ allergic cases and for the bath of the newbom, after pre-degermination by chlorhexidine at $4 \%$. 
Chlorhexidine is also used for cleaning contact lenses (0.005-0.006\%). To reduce populations greater than 5 $\log _{10}$ of $S$. marcescens, a MIC of $0.003 \%$ was reported to be equivalent to a $10 \mathrm{~min}$ exposure at a solution of $0.05 \%$ [11]. After $24 \mathrm{~h}$ contact time, the ability of $S$. marcescens to grow in chlorhexidine solutions at an interval of $0.001 \%$ to $0.006 \%$ was demonstrated [12].

\section{Glutaraldehyde (I.5-pentanedial)}

Glutaraldehyde, which exhibits high bactericidal, sporicidal, fungicidal, virucidal effectiveness, is widely used for high level disinfection of critical and semi-critical medical facilities, at a $2.0 \%$ concentration of an activated alkaline $(\mathrm{pH}=8.3)$ solution, for $6-10 \mathrm{~h}$ exposure [8]. To reduce populations over $08 \log _{10}$, the MICs were between $0.275 \%-0.375 \%(2750-3750 \mathrm{mg} / \mathrm{L})$ for B. subtilis, A. calcoaceticus, E. cloacae, and E. coli; an interval MIC of $0.1375-0.1875 \%(1375-1875 \mathrm{mg} / \mathrm{L})$ for S. marcescens, S. aureus and B. stearothermophilus.

\section{Comments}

Despite its antimicrobial effectiveness and beneficial annual cost, the side-effects of exposure to glutaraldehyde demand a safe work environment and a training program to assure worker safety standards [13], as well as its neutralization before pouring solutions down the drain [14]. Once all the residuals have been removed from the items by proper rinsing, glutaraldehyde will no longer represent a danger to the user.

\section{Formaldehyde (monoaldehyde)}

Formaldehyde is also selected for disinfection and airborne sanitization due to its antimicrobial (sporocidal, virucidal, fungicidal) activities. We observed that, for overnight decontamination of items, the use of a 0.5 to $1.0 \%$ formaldehyde aqueous solution provided a population reduction of $6-9 \log _{10}$, by an average MIC of 58.5 $\mathrm{mg} / \mathrm{L}$ for $S$. marcescens; of $117 \mathrm{mg} / \mathrm{L}$ for E. cloacae; of $156 \mathrm{mg} / \mathrm{L}$ for $S$. aureus and E. coli; of $235 \mathrm{mg} / \mathrm{L}$ for $B$. subtilis, and of $246 \mathrm{mg} / \mathrm{L}$ for B. stearothermophilus.

\section{Comments}

The use of formaldehyde, in Brazil [8], is permitted for high level disinfection of critical and non critical items articles, such as dialysis machines and reused dialyzers; drains and tubes in general, catheters; laparoscopes; artroscopes and ventiloscopes, acrylic grafts. These articles should be immersed for $18 \mathrm{~h}$, in an $8 \%$ formaldehyde alcoholic solution; followed by abundant rinsing in water or sterile physiologic solution or alcohol, preventing recontamination. In the preparation of parenteral solutions, water for injection (WFI) can be obtained through filtration by the osmose reverse system, the membrane of which can be disinfected in $18 \mathrm{~h}$ contact with an aqueous solution of 1.0\% formaldehyde, also followed by rinsing with a large amount of running water. The $8 \%$ formaldehyde alcoholic solution, which has been used, corresponds to a $2.0 \%$ formaldehyde aqueous solution, freshly prepared from a $37 \%(\mathrm{w} / \mathrm{v})$ formaldehyde solution, the industrial distillation of which resulted in a non-intoxicating solution, and a non-irritating vapor.

Furthermore, it is administered as a urinary antiseptic (dialysis [13]), with concentrations in the bladder of $100-200 \mathrm{mg} / \mathrm{L}$ [15]. Its releasing agents are also used in the treatment of severe peritonitis.

The disadvantages of formaldehyde is the loss of activity in the presence of organic matters; it is considered potentially cancerigenous $[10,13]$, and may cause eczema and sensitization.

\section{Alcohol (ethanol and isopropanol)}

Besides their broad antimicrobial activity, just as QACs and chlorhexidine, ethanol and isopropanol at $70 \%$ are not sporocidal, their effectiveness being due to the inhibition of germinating spores. To reduce populations over $06 \log _{10}$ of B. stearothermophilus, B. subtilis, S. aureus, $E$. cloacae, and E. coli, ethanol and isopropanol have shown a similar average MIC of $8.75 \%(87500 \mathrm{mg} / \mathrm{L}) . S$. marcescens and $A$. calcoaceticus were the most sensitive bacteria at a MIC of 4.375\% (43750 mg/L). Both alcohols have been largely applied on skin and semi-critical facilities, but they are not used for routine environmental cleaning, and may damage plastic tubes, acrylic and rubber facilities. The presence of $2 \%$ glycerin (emollient for hands and forearms) in ethanol at 70\% inhibited its activity on germinating spores. The addition of iodine $1 \%$ to ethanol at $70 \%$ reduced the alcohol MIC (4.375\%) to half for $E$. coli and S. aureus; and the addition of $10 \%(\mathrm{w} / \mathrm{v})$ iodine decreased the alcohol MICs to $4.375 \%$ and to $2.187 \%$ for B. subtilis and E. cloacae, and for S. aureus, respectively.

\section{Comments}

Ethanol is the preferred alcohol in Brazil. It is a by-product of sugar cane fermentation, being very easily encountered and cheap. In São Paulo Hospitals, in the central cleaning-disinfecting area, immersion of non-critical and semi-critical items in ethanol at $70 \%$ overnight has replaced phenol and formaldehyde solutions [16] and has been shown to be efficacious.

Alcohol has been added to sanitizing solutions (PVP- $\mathrm{I}_{2}$, chlorhexidine, formaldehyde) to prevent contamination with gram-negative bacteria, which are frequently found in hospital environments and can be responsible for the possible formation of a biofilm, hindering the penetration of the disinfectants. Alcohol is also used as a complementary pre-surgical topic antiseptic mixed to $\mathrm{PVP}-\mathrm{I}_{2}$ or 
chlorhexidine, the former having a rapid action and the latter, residual action [8]. Trautmann et al. (2001) [17] observed that strains of gram-negative bacteria were not regularly isolated from the hands of hospital personnel, which had been disinfected with alcohol before and after contact with patients.

After appropriate hand washing with disinfectant soap, disinfection of hands by using alcohol (alone or mixed with chlorhexidine or PVP- $\mathrm{I}_{2}$ ) is the best method for preventing outbreaks of infections in health care centers, as well as in food preparation establishments. Conrad (2001) [18] verified that in a 26o-bed teaching hospital (Switzerland), the consumption of alcohol increased in the sepsis of hands from $5.7 \mathrm{~L}$ hand alcohol per capita per year in 1990 to $9.1 \mathrm{~L}$ in 1998, due the introduction of the visualization test to detect the degree of hand disinfection of hospital staff without an increase in skin lesions. For the visualization test, the hands were completely covered with fluorescent alcohol. With a non-germicide lamp, in a dark environment, the areas of the skin which were fully covered, glowed yellow, while the non-covered areas were purple.

\section{lodine in polyvinyl-pyrolidone complex (PVP-I $\mathbf{2}_{2}$ )}

For aqueous (topic and soap) PVP- $\mathrm{I}_{2}$ solutions, the MIC varied from 0.625 to $1.250 \%$. For the alcoholic PVP-I $\mathrm{I}_{2}$ complex, the MIC varied from $0.1560 \%$ for $E$. coli to $1.250 \%$ for $A$. calcoaceticus and B. stearothermophilus. The highest MIC interval of $2.5-5.0 \%$ was for $B$. subtilis, independent of the solution.

\section{Comments}

The incorporation of $10 \% \mathrm{w} / \mathrm{v}$ iodine to the polyvinyl-pyrolidone (PVP- $\mathrm{I}_{2}$ ) complex strengthens the antibacterial effectiveness and reduces irritation on application. The aqueous PVP- $\mathrm{I}_{2}$ solution is recommended for topical asepsis; when added with non-ionic detergent (lauryl ether sulfate) it is used as a degerminating solution. The alcoholic PVP- $\mathrm{I}_{2}$ complex is indicated in delimitation of the surgical site. PVP- $\mathrm{I}_{2}$ can be used in the absence of chlorhexidine, assuring non allergic cases [8].

\section{Chlorine-Releasing-Agents (CRAs)}

The CRAs, as sodium hypochlorite $(\mathrm{NaOCl})$ and sodium dichloroisocyanurate (NaDCC), are extensively used for antiseptic and disinfecting purposes; and also for decontaminating non-critical surfaces with blood spillage in health care settings [19], despite decreased activity on storage and by organic matter. Similar MIC intervals were observed for the tested bacteria, considering an initial concentration of $8000-9000 \mathrm{mg} / \mathrm{L}$ free chlorine in $\mathrm{NaOCl}(\mathrm{pH} \geq 9)$ and NADCC ( $\mathrm{pH} 7.0)$ solutions. The most resistant gram-negative strains, E. coli and A. calcoaceticus, exhibited a similar MIC (1109.38 - $1497 \mathrm{mg}$ /
L); and for spores, the MIC was between $4000-5000$ $\mathrm{mg} / \mathrm{L}$. On adjusting the $\mathrm{pH}$ value to 7.0 of $\mathrm{NaOCl}$ solutions, the MIC values were reduced to one tenth, due to the higher predominance of HOCI, the formation of which was observed to stabilize at concentrations $\leq 0.1 \%$ CRAs, providing similar MIC $(150-300 \mathrm{mg} / \mathrm{L})$ values for the vegetative bacteria and a MIC of $621 \mathrm{mg} / \mathrm{L}$ for spores.

\section{Comments}

Sodium hypochlorite $(\mathrm{NaOCl})$ is traditionally used as a base for chlorine disinfectants, exhibiting a wide spectrum antimicrobial activity over a large range of temperatures. It is accessible, easily handled, non-toxic, and compatible with anionic and non-ionic detergents. The undissociated form hypochlorous acid $(\mathrm{HOCl})$ in water at $\mathrm{pH} 4-7$, which is responsible for the microbicidal inactivation by CRAs, has been shown to be 100 times more effective than the dissociated form $\mathrm{OCl}^{-}(\mathrm{pH}>9)[7,10]$. Commercial hypochlorite solutions $(\mathrm{pH}>8.0)$ should present a buffering capacity easily favoring dilution to $\mathrm{pH} 7.0$ or lower and accelerating formation of HOCl's strength.

In Brazil, $\mathrm{NaOCl}$ and $\mathrm{NaDCC}$ solutions at $1 \%(8000 \mathrm{mg} /$ $\mathrm{L}$ of free chlorine) are used for hard-surface disinfection of critical areas in hospitals (intensive therapy unit rooms, nurseries, wards, operating theatres, special procedure ambient) as well as, being added to previously untreated water. $\mathrm{NaOCl}$ solutions at $5000 \mathrm{mg} / \mathrm{L}(0.5 \%)$ are allowed to be used in the disinfection of oxygen therapy and anesthesia devices, for overnight exposure $[8,16]$. $\mathrm{NaOCl}$ solutions, stabilized with sodium chloride, may be applied in the disinfection of: (i) nursing bottles (flasks and teats) at concentration of $0.0125 \%(125 \mathrm{mg} /$ L), (ii) tableware and cutlery, at $0.025 \%(250 \mathrm{mg} / \mathrm{L})$, (iii) virus contaminated items, at $1.0 \%(10000 \mathrm{mg} / \mathrm{L})$ [19], (iv) tanks for preparing peritoneal dialysis solutions, at $0.1 \%(1000 \mathrm{mg} / \mathrm{L})$. Water used to remove residuals of the disinfectants, mainly from those items submitted to a high level disinfection with aldehyde products, must be free of gram-negative bacteria, the residual chlorine concentration being maintained in the range of 0.2 to 0.5 $\mathrm{mg} / \mathrm{L}[8]$.

\section{Hydrogen peroxide $\left(\mathrm{H}_{2} \mathrm{O}_{2}\right)$ and per acetic acid ( $\left.\mathrm{CH}_{3} \mathrm{COOOH}\right)$}

A Brazilian standard $\mathrm{H}_{2} \mathrm{O}_{2}$ solution at $4 \% \mathrm{w} / \mathrm{v}$ (400oo $\mathrm{mg} / \mathrm{L}$ ) was able to reduce populations over $08 \log _{10}$, and showed a MIC of 0.125 to $0.25 \%$ for $B$. subtilis and $B$. stearothermophilus; a MIC of 0.125 to $0.376 \%$ for E. coli, E. cloacae; a MIC of 0.0625 to $0.0938 \%$ for S. marcescens, S. aureus; and MICs of 0.0313 to $0.0625 \%$ for $A$. calcoaceticus. 
Peracetic acid (PAA) solution at $3 \%$, in accordance with our data, showed a range of MIC between $0.9-1.85 \%$ to reduce populations over $10^{9}$ of $B$. subtilis and gram-negative bacteria, and half of that (o.46\%) to reduce $S$. aureus and B. stearothermophilus populations, after $24 \mathrm{~h}$ contact.

\section{Comments}

Hydrogen peroxide is a powerful oxidizing agent, easily handled and non-toxic, applied on non-critical items. It is a mainstay in metal surface treatment, causing no damage in the disinfection of medical and dental devices in health care routine. It is also used for treating huge volumes of wastewater, and in water and food disinfection applications [8].

Sagripanti and Bonifacino (1997) [20] verified an undetectable effect of $25 \%$ serum on the sporocidal activity of $\mathrm{H}_{2} \mathrm{O}_{2}$, at concentrations lower than $10 \%(w / v)$. Because $\mathrm{H}_{2} \mathrm{O}_{2}$ is not affected by organic matter, the low concentrations used showed good sporocidal activity for $24 \mathrm{~h}$ exposure.

Peracetic acid (PAA) is considered a potent biocide at $\mathrm{pH}$ 2.0, decomposes to safe by products (acetic acid and oxygen) and remains unaffectedly active in the presence of peroxidases. Nevertheless, Sagripanti and Bonifacino (1997) [20] demonstrated that a serum at 5-25\% concentration reduced peracetic acid sporocidal activity about 1000 fold, due to the increase of pH to 5.0. PAA had its activity probably partially inhibited by the TSB presented in test tubes.

PAA can be used as a disinfectant of semi-critical medical devices (flexible scopes, hemodialysers) and environmental surfaces. However, it is severely irritating, and can form explosive mixtures with easily oxidized metal substances [8].

Rutala and Weber (1998) [19] remarked that, although the $2 \%$ glutaraldehyde-based formulations, $6 \%$ stabilized hydrogen peroxide and peracetic acid are among germicides categorized as chemical sterilants, they should be applied after adequate cleaning, following the proper guidelines in regard to organic load, contact time, temperature and $\mathrm{pH}$.

\section{Importance of liquid disinfection}

At the moment Brazil is being subjected to a strict control of energy consumption. The use of alternative electric equipment, like pasteurizers, has became untenable, because of their high consumption of energy, justifying the wide use of disinfectants which are cheaper and easily acquired and applied.
Another problem, in Brazil at the moment, is water rationing, due to the shortage of rain and the large population in urban areas. Although glutaraldehyde is recommended worldwide [10,19] for the high level disinfection of critical items and formaldehyde for sanitizing water equipment, both demand a large quantity of water for rinsing, in order to remove all residues from the surface of the items. An alternative would be to substitute the aldehydes by other disinfectants or even by associations between chemical agents, which demand less water for rinsing. Therefore, a better strategy would be to first wash the article with enzymatic detergents, thus making the surfaces more permeable, and increasing the action of disinfectants, in general.

\section{MIC method appliance}

The MIC method allows for comparisons between the microorganisms exposed to the same active chemical agents (biocides); but not between the activity of disinfectants. The presence of soil load, in the form of $5 \%$ of bovine serum albumin, represented here by the TSB, is recommended to be added to the bacterial test suspension as a challenge to the chemical agent activity [21]. The limitation of the MIC method is the unknown effect of the broth on each of the disinfectants, even though, the sequential dilution of which in mixture seems to overcome the interference of the broth.

The MIC method shows the range of disinfectant activity over a specific group, genera or strain of bacteria, suggesting the organism which should be used as a biological indicator (BI) to verify the specific chemical activity on a specific application. The MIC method is also used to select a commercial sanitizer containing the same biocide against the same BI. To verify the performance of the disinfectant against an organism on a specific surface, the decimal reduction time (D-value) should be investigated, taking into consideration the resistance of the same organism in direct contact with the biocide.

\section{Conclusions}

Dilution of the chemical agent to the appropriate bactericidal concentration must be effected with clean potable water. Meanwhile, direct contact with dirty materials should be avoided, the presence of which cause gradual loss of strength and become a vehicle of contamination to other surfaces. Solutions of chemical agents should be kept in closed containers, well protected from air contaminants and provided with a facility which releases a constant required amount.

All over the world, liquid disinfectants are widely employed for their benefit-cost effect. For use in hospitals, the chemical disinfectant should be very easily handled, harmless, and effective for use by nurses caring for chil- 
dren, thus preventing cross-infections. The misuse of chemical agents can develop resistant strains of pathogenic microorganisms. Even with the best disinfectants, sterilants, hand washes, and surgical scrubs, cross contamination and infections will occur without proper use of the products. It is essential to adequately control the concentration of diluted products, the contact time of the product, and the cleanliness of the surface prior to disinfection [19]. The tested bacteria are commonly found in the human gastro-intestinal and upper-respiratory tracts, and also in normal skin flora. The correct use of disinfecting agents should be emphasized by educational training and be included in control measures in health care centers, to minimize the risk of cross-infections. The development of hygiene programs standardize the way the chemical agents should be handled.

\section{Competing Interests section}

None declared

\section{Acknowledgement}

We gratefully acknowledge to Brazilian Committees FAPESP and CNPq for the undergraduate scholarships and funds; the assistance of Biologist Irene Machoshvili and Edwards Lifesciences Macchi; and the English revision by Norah Duncan.

\section{References}

I. World Health Organization (WHO): Weekly Epidemiological Record 1997, 72:285-356

2. Brazilian Pharmacy Council: Maternity hospital infection. Pharmacia Brasileira 2000, 3:37

3. Pan American Health Organization (PAHO): Celebrating 95 years: 1902-1997: Protecting Americas' Health 1997|-3

4. Pan American Health Organization (PAHO): Integrated Management of Childhood (IMCI): "Healthy children: Goal 2002". Epidemiological Bulletin 1999, 20(4):3-6

5. Brazilian Pharmacy Council: PAHO: Program to reduce deaths of babies in Brazil. Pharmacia Brasileira 2000, 3:34

6. Vessoni Penna TC, Machoshvili IA, Taqueda MES: Bacillus stearothermophilus sporulation response to different composition media. PDA J Pharm Sci and Techn 1998, 52 (5): 1 98-208

7. Vessoni Penna TC, Schaffner D, Abe LE, Machoshvili IA: Inactivation of Brazilian wild type and enterotoxigenic Escherichia coli by chlorine. I Ind Microbiol 1996, 16:57-6I

8. Brazilian Ministry of Health's Directives: $n^{\circ}$ I 5/MS/ANVS $n^{\circ} 2$ I I/ MS/ANVS 1999, $n^{\circ}$ I96/MSIAVNS 1983, $n^{\circ}$ II3/MS/AVNS I 993, $n^{\circ}$ I 22/DTN 1993, $n^{\circ} 2$ I I/MS/ANVS I 999, Health Sanitation Code $n^{\circ}$ 12342,1978

9. Tavares LC, Vessoni Penna TC, Amaral AT: Synthesis and biological activity of nifuroxazide and analogs. Boll Chim Farmaceutico 1997, 3:244-249

10. McDonnell G, Russell AD: Antiseptics and disinfectants: activity, action, and resistance. Clin Microbiology Review 1998, 12 (I): $147-179$

II. Denton GW: Chlorhexidine. In: Disinfection, sterilization, and preservation. (Edited by S.S. Block, 4th ed) Philadelphia: Lea \& Feabiger 1991322333

12. Gandhi PA, Sawant AD, Wilson LA, Ahearn DG: Adaptation and growth of Serratia marcescens in contact lens disinfectant solutions containing chlorhexidine gluconate. Appl Environ Microbiol 1993, 59:183-188

13. Weber DJ, Rutala WA: Occupational risks associated with the use of selected disinfectants and sterilants. In: Disinfection, Sterilization and Antiseptics in Health Care (Edited by Rutala WA) New York, Polyscience Publishers 1998217-220

14. Kenneth JR: Sterilization, Pasteurization and Desinfection. In : Sherris Medical Microbiology: an Introduction to Infectious Diseases (Edited by Kenneth JR, 3rd ed) New York, Appleton and Lange 1994I7I-I78
15. Kessler M, Huu TC, Mariot A, Chanliau J: Hemodialysis associated complications due to sterilizing agents ethylene oxide and formaldehyde. Control Nephrol 1988, 62:13-23

16. Diaz RB, Vessoni Penna TC, Takeuti CE, Taira ET, Guimarães T: Centralization of disinfection of semi-critical and non-critical items in a Brazilian Hospital (Saint Cruz Hospital): economical improvement of sanitizing procedures. (Centralização do processo de desinfecção de materiais semi-críticos e nãocríticos no Hospital Santa Cruz: melhoria da qualidade e redução de custos). Laes \& Haes 2000, I 28 (6):68-78

17. Traumann M, Michalsky T, Wiedeck H, Radosavljevic V, Ruhnke M: Tap Water Colonization with Pseudomonas aeruginosa in a surgical intensive care unit (ICU) and relation to Pseudomonas infections of ICU patients. Infect Control Hosp Epidemiol 2001, 22:49-52

18. Conrad RN: Increasing in hand-alcohol consumption among medical staff in a general hospital as a result of introducing a training program and a visualization test. Infect Control Hosp Epidemiol 200I, 22:4I-2

19. Rutala WA, Weber DJ: Principles of disinfecting patient-care items. In: Disinfection, Sterilization and Antiseptics in Health Care (Edited by Rutala WA) New York, Polyscience Publishers 1998133-149

20. Sagripanti JL, Bonifacino A: Effects of salt and serum on the sporocidal activity of liquid disinfectants. J AOAC Intern 1997, 80 (6): I 198-1207

21. Sattar SA: Microbicidal testing of germicides: an update. In: Disinfection, Sterilization and Antiseptics in Health Care (Edited by Rutala WA) New York, Polyscience Publishers 1998227-240
Publish with BioMed Central and every scientist can read your work free of charge

"BioMedcentral will be the most significant development for disseminating the results of biomedical research in our lifetime." Paul Nurse, Director-General, Imperial Cancer Research Fund

Publish with BMC and your research papers will be:

- available free of charge to the entire biomedical community - peer reviewed and published immediately upon acceptance - cited in PubMed and archived on PubMed Central

- yours - you keep the copyright 